\title{
GERMAN-POLISH RELATIONS. POLITICAL AND ECONOMIC ASPECTS
}

\author{
Rafał Ulatowski ${ }^{1}$ \\ University of Warsaw
}

\begin{abstract}
:
The aim of this article is to analyze the Polish-German relations in the last 25 years. The article will concentrate on the expectations declared in the early 1990s as well as on the results that were achieved. I argue that economic strength was successfully used by the German government to give German-Polish relations a new quality. Polish-German relations are an example of successful implementation of geo-economics strategy by the German government.
\end{abstract}

Keywords: Poland, Germany, geo-economy, European Union, NATO.

\section{Resumen:}

El objetivo de este artículo consiste en analizar las relaciones entre Polonia y Alemania en los últimos 25 años. El artículo se centra en la explicación de las expectativas declaradas a principios de los años noventa y los resultados obtenidos. El autor señala que el gobierno alemán utilizó con éxito su fortaleza económica dando a las relaciones bilaterales una nueva naturaleza. Las relaciones bilaterales constituyen un ejemplo del éxito de la puesta en práctica de una estrategia geo-económica por parte del gobierno alemán.

Palabras clave: Polonia, Alemania, geo-economía, Unión Europea, OTAN.

Copyright $($ C UNISCI, 2016.

Las opiniones expresadas en estos artículos son propias de sus autores, y no reflejan necesariamente la opinión de UNISCI. The views expressed in these articles are those of the authors, and do not necessarily reflect the views of UNISCI.

\footnotetext{
${ }^{1}$ Rafał Ulatowski, is assistant professor, Institute of International Relations University of Warsaw. Main research areas: German Foreign Policy, Polish-German relations, international energy market, international economic relations.

E-mail: r.ulatowski@uw.edu.pl.

http://dx.doi.org/10.5209/rev_RUNI.2016.n40.51805
} 


\section{Introduction}

The collapse of the Soviet Empire in Central and Eastern Europe and the unification of Germany in 1990 opened a new chapter in Polish-German relations. During the Cold War, the Federal Republic of Germany (FRG) and Poland were parts of different political alliances hostile to each other. Their relations were burdened by the historically grounded hostility and ideological competition. ${ }^{2}$ In 1989/1990, the elites of Poland and the FRG, and then of the united Germany, decided to overcome the deficits of Polish-German relations and open a new chapter in bilateral relations. That was a historical decision. From the very beginning it was clear that it would be linked with the process of European integration, which was a priority of both governments. $^{3}$

The aim of this article is to analyze the Polish-German relations in the last 25 years. Due to limited space it will concentrate on their beginnings and the expectations expressed in the early 1990s as well as on the achieved results. I argue that economic strength was successfully used by the German government to give German-Polish relations a new quality. Polish-German relations are an example of successful implementation of geoeconomic strategy by the German government.

The article has the following structure: First, I will discuss the character of power in the post-Cold War international system. Then I will discuss the national interests of both countries in the early 1990s. In the third part I will analyze the Polish-German community of interests. In the fourth part I will analyze the development of Polish-German economic relations, and finally I will look at the current state of Polish-German relations.

\section{The Nature of Power in the post Cold War International System}

During the Cold War world politics was dominated by the competition between two superpowers: the United States and the Soviet Union. It was best described by the theory of political realism, which emphasized the role of anarchy in international relations and described the state as a dominant and rational actor in international relations pursuing its own national interests. The main goal of the state was security, mostly understood as military security. ${ }^{4}$ With the changes in international relations that took place in the $1970 \mathrm{~s}$, the explanatory power of realism was falling more and more under criticism. The growing interdependences and the role of private actors exacerbated the criticism of realism. Neoliberalism, represented in particular by Robert Keohane and Joseph Nye, was an answer to the new dilemmas. But as Keohane commented in one of his publications, realism was a "good starting point for the analysis of cooperation and discord, since its taut logical structure and its pessimistic assumptions about individual and state behavior serve as barriers against wishful thinking", ${ }^{5}$ to which he added: "ironically, my $[\ldots]$ theory, focused on the interaction

\footnotetext{
${ }^{2}$ Bingen, Dieter: "Der lange Weg der „Normalisierung". Die Entwicklung der Beziehungen zwischen der Bundesrepublik Deutschland und Polen 1949-1990", in: Eberwein, Wolf-Dieter; Kerski, Basil (eds.) (2001): Die deutsch-polnischen Beziehungen 1949-2000. Eine Werte- und Interessengemeinschaft?, Opladen, Leske + Budrich, pp. 35-59; Misala, Józef: "Die deutsch-polnischen Wirtschaftsbeziehungen vor und nach der deutsche Einheit", Osteuropa-Wirtschaft, vol. 39, no. 1 (1994), p. 42-54.

${ }^{3}$ Bingen, Dieter (1998): Die Polenpolitik der Bonner Republik von Adenauer bis Kohl 1949-1991, Nomos, Baden-Baden.; Tomala, Mieczysław(2000): Deutschland- von Polen gesehen. Zu den deutsch-polnischen Beziehungen 1945-1990, Schüren, Marburg.

${ }^{4}$ Morgenthau, Hans (1948): Politics Among Nations, New York: Knopf.; Waltz, Kenneth (1979): Theory of International Politics, New York, McGraw Hill.

${ }^{5}$ Koehane, Robert O. (2005): After Hegemony. Cooperation and Discord in the World Political Economy, 2. ed., Princeton University Press, New Jersey, p. 245.
} 
of states, may have given too much credit to the Realist anarchy paradigm that it sought to criticize". ${ }^{6}$

The end of the Cold War opened the quest for the right explanatory model that could properly explain the role of the state in international relations. Special attention should be given to the theory proposed by Edward Luttwak, who questioned the utility of military power but did not question the anarchical nature of international relations and the domination of national interest in state policy. He argued that states in the post-Cold War system used economic rather than military means to achieve national goals. With the absence of a military threat, economic goals (competitiveness of the economy and national wealth) were also described as a priority for the states. Luttwak argued in favor of cooperation between states and corporations. For him, military conflicts were uneconomic and thus unacceptable. He observed that competition between powers is substantially economical. ${ }^{7}$ This observation proved to be right. ${ }^{8}$ In the next two decades states concentrated on developing their economic potential and reduced their military spending. Luttwak had many followers and today his ideas are well developed. Economic strength is seen as both a goal and an instrument of state policy. Development of economic power was considered as a priority for the state. ${ }^{9}$

The unification of Germany in 1990 opened a discussion about the country's future foreign policy. Although Chancellor Helmut Kohl tried to convince other governments and public opinion that united Germany would stay faithful to the foreign policy principles of the FRG (close relations with the USA and France, good relations with neighboring states and engagement in the process of European integration), ${ }^{10}$ doubts were not eliminated. Different concepts of foreign policy were discussed. The most popular were: the central power of Europe, ${ }^{11}$ civilian power ${ }^{12}$ and trade state. ${ }^{13}$ Special attention was paid to the economic dimension of German foreign policy. ${ }^{14}$ Already during the Cold War, the FRG was able to hide behind the US security umbrella and focus on achieving its economic goals. After World War II, the FRG was also reluctant to use military power as an instrument of foreign policy. After the reunification, a long discussion about "normality" ${ }^{15}$ of the German foreign policy

\footnotetext{
${ }^{6}$ Ibid., pp. xvi.

${ }^{7}$ Luttwak Edward. N.: "From Geopolitics to Geo-Economics: Logic of Conflict, Grammar of Commerce", in Tuathail, Gearóid Ó.; Dalby, Simon; Routledge, Paul (eds.) (1998): The Geopolitics Reader, Routledge, London, p. $125-130$.

${ }^{8}$ Chung, Jae W. (2015): Global Economic Disparity: A Dynamic Force in Geoeconomic Competition of Superpowers, Lexington Books, Lanham.

${ }^{9}$ Savona, Paolo, Jean Carlo (ed.) (1995): Geoeconomia - Il dominio dello spazio economico, Franco Angeli, Milano.; Lorot, Pascal: "La géoéconomie, nouvelle grammaire des rivalités internationals", Annuaire Français de Relations Internationals 2000, p. 110-122.

${ }^{10}$ Haftendorn, Helga: "Maximen deutscher Außenpolitik- Von der Regierung Kohl über Schröder zu Merkel", in Meier-Walser, Reinhard; Wolf, Alexander (eds.) (2012): Die Außenpolitik der Bundesrepublik Deutschland. Anspruch, Realität, Perspektiven, München: Hanns-Seidel-Stiftung, pp. 16.

${ }^{11}$ Schwarz, Hans-Peter (1994): Die Zentralmacht Europas. Deutschland Rückkehr auf die Weltbühne, Berlin: Siedler Verlag.

${ }^{12}$ Maull, Hans W: "Germany and Japan: The New Civilian Powers", Foreign Affairs, vol. 69, no. 5 (1990),pp. 91-106.

${ }^{13}$ Staack, Michael (2000): Handelsstaat Deutschland. Deutsche Außenpolitik in einem neuen internationalen System, Paderborn, Ferdinand Schöningh Verlag.

${ }^{14}$ Schumann, Hartmut: "Wirtschaftliche Dimension der Außenpolitik", Zeitschrift für Politik, vol. 41, no. 2 (1994),pp. 146-161.

${ }^{15}$ Kessler, Sebastian; Schewe, Johann; Weber, Christian: "Normalität", in Link, Werner; Weber, Christian; Sauer, Frank (eds.) (2008): Die Semantik der neuen deutschen Außenpolitik. Eine Analyse des außenpolitischen Vokabulars seit Mitte der 1980er Jahre, Wiesbaden, VS Verlag für Sozialwissenschaften, pp. 126-134.
} 
took place. In the $21^{\text {st }}$ century attention shifted toward the concept of geo-economy. Germany was defined in literature as a geo-economic power. ${ }^{16}$

In this article I will follow the geo-economic approach, which is the most convenient explanatory model of the European affairs and German foreign policy in the post Cold War era.

\section{The National Interests of Germany and Poland after 1990}

In February 1989, the Polish government started negotiations with the Solidarność (Solidarity) opposition (the Round Table Talks). They led to partially democratic elections held on June $4^{\text {th }}$ and $18^{\text {th }}, 1989$, which ended with the victory of the opposition. A few months later, Tadeusz Mazowiecki was elected prime minister and Leszek Balcerowicz became minister of finance. Political and economic reforms followed. A "shock therapy" was implemented in economic affairs, and the foreign policy experienced its own shock as well, being re-oriented towards the West. The new key goals were accession to NATO and to the European Communities. It was clear to the new designers of the Polish foreign policy that Poland could achieve its goals only with German (and French) support. ${ }^{17}$

In early November 1989, Chancellor Helmut Kohl visited Poland with the aim of reconstructing the Polish-German relations. The visit was full of symbolical gestures of historical importance, their peak being the holy mass held in Krzyżowa on November $12^{\text {th }}$, 1989. Reconciliation was the declared the goal of both governments. However, the visit had a very practical dimension as well. Eleven bilateral agreements were signed and a joint declaration was issued. ${ }^{18}$ Chancellor Kohl indicated during his talks with the Polish president that Germany wished to have equally good relations with Poland as with France. ${ }^{19}$ During the $6^{\text {th }}$ Poland-Germany Forum on February 22 $2^{\text {nd }}, 1990$, Polish Foreign Minister Kszysztof Skubiszewski argued in favor of the "Polish-German community of interests". ${ }^{20}$

Since the early 1990s, Polish-German relations have been determined by two expectations: first, they should achieve the quality of the French-German relations and second, a "Polish-German community of interests" should emerge.

In the late 1989 and the early 1990 unification of Germany was again a major topic in the international arena. Poland supported the unification and raised two arguments for it: first, Germans should enjoy the same right as other European nations to live in a free, democratic, united, and sovereign country; second, only a united Germany could support Poland in its plans to join the European Communities and NATO.

\footnotetext{
${ }^{16}$ Kundnani, Hans: "Germany as a Geo-economic Power", The Washington Quarterly, vol. 34, no. 3, (2011), p. 31-45.; Szabo, Stephen F. (2014): Germany, Russia, and the Rise of Geo-Economics, London, Bloomsbury Academic

${ }^{17}$ Kuźniar, Roman (2008): Poland's Foreign Policy, Warsaw, Wydawnictwo Naukowe Scholar, p. 64-65.

${ }^{18}$ Zięba, Ryszard (2010): Główne kierunki polityki zagranicznej Polski po zimnej wojnie, Wyd. 1. Warszawa, Wydawnictwa Akademickie i Profesjonalne, p. 39.

19 Bartoszewski, Władysław: "Angst vor der Großmacht? Deutschland und Polen nach dem Umbruch", Internationale Politik, vol. 55, no. 9 (2000), p. 10.

20 Skubiszewski, Krzysztof: "Przemówienie Ministra Spraw Zagranicznych RP prof. dr hab. Krzysztofa Skubiszewskiego- wygłoszone podczas VI Forum Rzeczpospolita Polska- Republika Federalna Niemiec podczas przyjęcia w Hotelu Polonez", in Tomala, Mieczysław (eds.) (2006): Polityka i dyplomacja polska wobec Niemiec Tom II 1971-1990. Wstęp, wybór i opracowanie dokumentów, Warszawa, Dom Wydaw. Elipsa, pp. 659-662.; See: Eberwein, Wolf-Dieter; Ecker-Ehrhardt, Matthias (2001): Deutschland und Polen - Eine Werte- und Interessengemeinschaft? Die Eliten-Perspektive, Opladen, Springer VS, p. 17-24.
} 
Germany and Poland confirmed the existing border between them in the treaty of November $14^{\text {th }}, 1990 .^{21}$ As a way to support the development of friendly relations between them on June $17^{\text {th }}, 1991$ they signed the "Treaty of Good Neighborhood and Friendly Cooperation". ${ }^{22}$ It provided a framework for Polish-German cooperation in the next decades. Special attention was paid to the European dimension of bilateral cooperation. Germany declared support for the Polish ambition to join the European Communities. ${ }^{23}$ The treaty regulated also a wide range of issues and became the foundation of the current Polish-German relations.

In consequence of the treaty, Polish-German relations were institutionalized. A broad range of organizations and institutions emerged. The most important was the German-Polish Youth Office (Pol.: Polsko-Niemiecka Współpraca Młodzieży; Ger.: Deutsch-Polnisches Jugendwerk). Its goal is to finance projects aimed at children and youth. This idea was based on experiences of a similar German- French organization.

In the 1990s Germany took the central role in European politics. This was immediately noticed by Poland, which saw Germany as a country that practically determined the political and economic development in the EU. ${ }^{24}$ On the other hand, German politicians still saw Poland as a country being deep in the shadow of Russia. In time, the perspective of the German elites changed, ${ }^{25}$ but the special sensitivity to Russian interests persisted.

The eastern enlargement of the European Communities did not enjoy support in all Western European countries. Especially French President François Mitterrand was skeptical. On the one hand, France was worried about possible dominance of Germany in Central Europe, but on the other hand, France wanted to strengthen its traditional ties with countries in this part of Europe. Polish elites did not want to be fully dependent on Germany in its European policy either. This mixture of interests led to the emergence of the Weimar Triangle in 1991. The consultation group composed of Germany, France and Poland was supposed to build mutual trust and work in favor of European integration. ${ }^{26}$

The German national interests in the new international reality were first officially defined in the White Book of $1994 .{ }^{27}$ Germany saw itself as the biggest winner of the transformation in Central Europe. ${ }^{28}$ It saw a chance to become one of the leaders and co-

\footnotetext{
${ }^{21}$ Vertrag zwischen der Bundesrepublik Deutschland und der Republik Polen über die Bestätigung der zwischen ihnen bestehenden Grenze, vom 14.11.1990, at http://www.auswaertiges-amt.de/diplo/de/AAmt/PolitischesArchiv/DokumenteUndVertraege/901114VertDeuPL Grenzen-pdf.pdf.

${ }^{22}$ Vertrag zwischen der Bundesrepublik Deutschland und der Republik Polen über gute Nachbarschaft und freundschaftliche Zusammenarbeit, vom 17.6.1991, at

http://www.auswaertiges-amt.de/diplo/de/AAmt/PolitischesArchiv/Dokumente und

Vertraege/910617-VertDeuPLFreund-pdf.pdf.

${ }^{23}$ Ibid., Art.8(3).

${ }^{24}$ Bingen, Dieter: "Aspekte von Wandel und Kontinuität im polnischen politischen Denken über Deutschland von 1966 bis 1991", in Bingen, Dieter; Więc, Janusz Józef (eds.) (1993): Die Deutschlandpolitik Polens 19451991. Von der Status-quo-Orientierung bis zum Paradigmenwechsel, Kraków, Zeszyty Naukowe Uniwersytetu Jagiellońskiego, p. 174.

${ }^{25}$ Cichocki, Marek A.: "Polish-German Relations in the Light of Poland's Accession to the European Union", The Polish Foreign Affairs Digest, no. 2 (2002), p. 170.

${ }^{26}$ Weber, Pierre-Frédéric: "Das 'Weimarer Dreieck' Vom Gründungsoptimismus zur neuen Sinnsuche", in Bingen, Dieter; Loew, Peter Oliver; Ruchniewicz, Krzysztof; Zybura, Marek (eds.) (2011): Erwachsene Nachbarschaft: die deutsch-polnischen Beziehungen 1991 bis 2011, Wiesbaden, Harrassowitz Verlag, p. 77-91.

${ }^{27}$ Weißbuch zur Sicherheit der Bundesrepublik Deutschland und zur Lage und Zukunft der Bundeswehr, Köln 1994.

${ }^{28}$ Ibid., p. 24.
} 
designers of the new European order. ${ }^{29}$ The White Book indicates five goals of the German foreign policy for the next decade. One of them was accession of Germany's eastern neighbors to Western European organizations. ${ }^{30}$ The White Book of 1994 indicates three terms that should characterize the German foreign policy toward countries in Central and Eastern Europe: stability, cooperation and integration. ${ }^{31}$ The German government saw no alternative to the eastern enlargement of the EU, and it considered itself the advocate of this process. ${ }^{32}$ There was also a strong economic incentive to support it. The German industry hoped for new markets, investment opportunities and a source of cheap natural resources and semi-finished products. ${ }^{33}$ The goal of the German policy was to replace the Yalta Order with a "Brussels Order". ${ }^{34}$ Helmut Kohl was convinced that the eastern enlargement was in Germany's national interest. ${ }^{35}$

German interests coincided with the Polish ones. The aim of Polish foreign policy in the 1990s was to obtain membership in Western European institutions and NATO, keep USA engaged in European affairs, develop good relations with Poland's neighbors in Central and Eastern Europe. ${ }^{36}$ The accession to the European Union enjoyed the highest priority. ${ }^{37}$ This was motivated by a combination of political and economic aspects of the Polish national interest. This goal was broadly supported by the political class and the Polish society. ${ }^{38}$

As former Polish ambassador in Berlin, Janusz Reiter, suggested, the issue of Polish accession to the European Union was closely connected with the question about the quality of the German-Polish relations. He drew the comparison with the situation of France. He expressed the view that for Poland and France alike the European policy was very close to German politics. ${ }^{39}$ On the way to the EU, Germany was seen as a partner of "extraordinary importance". ${ }^{40}$

\section{The Polish-German Community of Interests and its Critique}

Poland and the European Economic Community had signed an agreement on trade and

${ }^{29}$ Ibid., p. 24-27.

${ }^{30}$ Ibid., p. 42.

${ }^{31}$ Ibid., p. 44.

${ }^{32}$ Kinkel, Klaus: "Erklärung der Bundesregierung. Deutsche Präsidentschaft im Rat der Europäischen Union, abgegeben vor dem Deutschen Bundestag", in Presse- und Informationsamt der Bundesregierung (eds.) (1994): no. 63, Bonn, p. 594.

33 Haftendorn, Helga: "Gulliver in der Mitte Europas. Internationale Verflechtung und nationale Handlungsmöglichkeiten", in Kaiser, Karl ; Maull, Hanns W. (eds.) (1997): Deutschlands neue Außenpolitik. Band 1: Grundlagen, 3. Aufl., München, Oldenbourg Wissenschaftsverlag, p. 142.

${ }^{34}$ Lippert Barbara: "Die EU-Erweiterungspolitik nach 1989 - Konzeption und Praxis der Regierung Kohl und Schröder", in: Schneider, Heinrich; Jopp, Mathias ; Schmalz Uwe (eds.) (2001): Eine neue deutsche Europapolitik? Rahmenbedingungen-Problemfelder-Optionen, Bonn, Europa Union Verl, p. 358.

${ }^{35}$ Lippert, Barbara: "Deutschlands spezielles Interesse", in: Franzmeyer, Fritz; Weise, Christian (eds.) (1996): Polen und die Osterweiterung, Berlin, Duncker \& Humblot, p. 131.

${ }^{36}$ Skubiszewski, Krzysztof: "Racja stanu z perspektywy polskiej", Rocznik Polskiej Polityki Zagranicznej 1992, (1994), p. 38.

${ }^{37}$ Ibid., p. 40.

${ }^{38}$ Ibid., p. 41.

${ }^{39}$ Reiter, Janusz: "Stosunki z Niemcami", Rocznik Polskiej Polityki Zagranicznej 1996, Warszawa 1996, p. 109.; Weber, Pierre-Frédéric: "Frankreich, Deutschland und Polen im europäischen Einigungsprozess. Französische Rollen im Wandel der Zeit 1968-2008", in Hilz, Wolfram; Robert, Catherine (eds.) (2010): FrankreichDeutschland-Polen. Partnerschaften im Herzen Europas, Bonn, ZEI Discussion Paper, p. 15.

${ }^{40}$ Skubiszewski, Krzysztof: "Deutschland: Anwalt Mitteleuropas. Eine polnische Sicht der deutschen EuropaPolitik", Internationale Politik, vol.52, no. 2 (1997), p. 30. 
commercial and economic cooperation on 19 September $1989 .{ }^{41}$ It was a step toward trade liberalization, but it offered relatively small progress. Much more favorable for Poland was the decision of the European Commission of November 1989. This is why most provisions of the agreement from September 1989 didn't enter into force. ${ }^{42}$ The political revolutions that took place in spring and summer of 1989 in Central and Eastern European countries inspired the EEC to take decisive steps. The Phare program was created in July 1989 and the Commission took the leading role, Poland was invited to the Generalized System of Preferences, and quantitative restrictions for imports from Poland were mostly eliminated. With these steps the trade liberalization between the EEC and Poland started. ${ }^{43}$

The next step was the association agreement between Poland and the European Communities from 1991, which clearly indicated that the association is only a step toward the integration of Poland with the European Communities. ${ }^{44}$ The association agreement was signed on 16 December 1991 in Brussels. ${ }^{45}$ As Polish Foreign Minister, Władysław Bartoszewski, indicated before the second official state visit of Helmut Kohl in Poland in 1995, in Poland's eyes Germany rose to the position of "strategic partner in all areas". ${ }^{46}$ The goal of Polish and German politicians was to integrate the bilateral cooperation between the two countries stronger in European politics. Germany was keen to support Poland's accession to the European Union, and Chancellor Kohl even declared during his visit to Poland in 1995 that Poland should join the EU by the end of the $20^{\text {th }}$ century. ${ }^{47}$ In December 1997 the European Council in Luxembourg decided to start accession negotiations with Poland. They ended on April 16 ${ }^{\text {th }}, 2003$ as the Accession Treaty was signed. It is clear that the eastern enlargement of the EU would not be possible without German engagement in this process.

Although there were occasional conflicts, the quality of Polish-German relations in the 1990s is very positively assessed. The most notable conflict was over the interpretation of the common history. It was initiated by the declarations of the Bundestag (May 29 ${ }^{\text {th }}, 1998$ ). The Polish Sejm answered with the declaration of July $3^{\text {rd }}, 1998$. But at that time the elites of the two countries were determined to play these differences down. The 1990s were the "golden age" in Polish-German relations. ${ }^{48}$

\footnotetext{
${ }^{41}$ Agreement between the European Economic Community and the Polish People's Republic on trade and commercial and economic cooperation, 19.9.1989, in: Abl. 1989, L 339, 22.11.1989, p. 2-52.

${ }^{42}$ Kawecka-Wyżykowska, Elżbieta; Synowiec, Ewa: "Droga Polski do Unii Europejskiej", in Elżbieta KaweckaWyżykowska/ Ewa Synowiec (eds.) (2004): Unia Europejska T1, Warszawa, Instytut Koniunktury i Cen Handlu Zagranicznego, p. 428.

${ }^{43}$ Ibid.

${ }^{44}$ Zięba, Ryszard (2010): Główne kierunki polityki zagranicznej Polski po zimnej wojnie, Wyd. 1. Warszawa, Wydawnictwa Akademickie i Profesjonalne, p. 104

45 Europa-Abkommen zur Gründung einer Assoziation zwischen den Europäischen Gemeinschaften und ihren Mitgliedstaaten einerseits und der Republik Polen andererseits - Protokoll Nr. 1 über die Bestimmungen für die Textilwaren - Protokoll Nr. 2 über die Bestimmungen für die unter den Vertrag über die Gründung der Europäischen Gemeinschaft für Kohle und Stahl fallenden Erzeugnisse - Protokoll Nr. 3 über die Handelsbestimmungen für die landwirtschaftlichen Verarbeitungserzeugnisse - Protokoll Nr. 4 über die Ursprungsregeln für die Gewährung der Zollpräferenzen - Protokoll Nr. 5 enthält die Sonderbestimmungen für den Handel zwischen der Republik Polen einerseits und Spanien und Portugal andererseits - Protokoll Nr. 6 über Amtshilfe im Zollbereich - Schlussakte - Gemeinsame Erklärungen der Vertragsparteien, in: $A B l$. $1993 \mathrm{~L}$ 348 vom 31.12.1993, p. 2-180.

46 "Deutschland wichtiger strategischer Partner Polens", FAZ, 3 July1995, p. 1.

${ }^{47}$ Kohl, Helmut: "Rede von Bundeskanzler Helmut Kohl anlässlich der Eröffnung der Deutsch-Polnischen Industrie- und Handelskammer am 7. Juli 1995 in Warschau", in Presse- und Informationsamt der Bundesregierung (eds.) (1995): Bulletin Nr.58, Bonn, p. 574.

${ }^{48}$ Kerski, Basil (2011): Die Dynamik der Annäherung in den deutsch-polnischen Beziehungen: Gegenwart und Geschichte einer Nachbarschaft, Düsseldorf, düsseldorf university press, p. 240-265
} 
But as the two main goals in the bilateral relations were achieved in the early $21^{\text {st }}$ century, the relations entered a new phase. As a one of the best known experts in PolishGerman relations, Dieter Bingen - Director of the German Institute of Polish Studies (Deutsches Polen-Institut) in Darmstadt - summarized, the successful closure of the Polish accession negotiations was also the end of the "paternalistic-clientelistic relation, the end of the role of Poland as a junior partner of Germany and junior position of Poland in the Weimar Triangle". ${ }^{49}$ Differences between both governments came more into focus. The list was long: a new treaty for the EU (a Constitution for Europe), European-American relations, the energy relations with Russia (Nord Stream) and relations with Russia more generally, historical policy (Centre Against Expulsions). ${ }^{50}$ Those were only the most important issues. The atmosphere in the Polish-German political relations deteriorated substantially. It seems that the focus on enlargement of the EU and NATO resulted in both governments leaving too many issues unresolved. It was high time for an unpleasant but frank discussion was needed. ${ }^{51}$

At the end of the first decade of the $21^{\text {st }}$ century, the atmosphere in the mutual relations improved again. Opposition against German plans was unsuccessful. The Treaty of Lisbon became reality and the Nord Stream pipeline was built. Also German historical policy did not change. As the previous Polish ambassador said, after the "romantic" phase of Polish-German relations, there was a phase of "pragmatic cool-down", which in turn was followed by both countries going into the phase of "mature partnership". ${ }^{52}$ The new strategy concentrated on strategic rapprochement with Germany. Beside the Polish-German issues, it was motivated by the rising position of Germany in the EU. The financial crisis and then the euro-crisis strengthened Germany. German financial power was needed to manage the euro-crisis. Some observers began seeing Germany as the European hegemon. ${ }^{53}$ Although this thesis seems to exaggerate German power, it was needed for the Polish foreign policy to find an answer to the new international balance of power. Two declarations need to be mentioned in this context. The first one is the speech of the Polish foreign minister Radosław Sikorski in DGAP on November $28^{\text {th }}, 2011$. He argued in favor of Germany playing a more active role in the EU. He expressed the wish for Germany to help resolve problems in Europe. He ended his speech with the famous sentence "I fear German power less than I am beginning to fear German inactivity". ${ }^{54}$ The second important but also symbolic gesture was the proposal of Polish President, Bronisław Komorowki, during his speech in the German Bundestag on the 75 anniversary of the beginning of World War II, which concerned the need for "Polish-German responsibility partnership for the future of Europe". ${ }^{55}$

\footnotetext{
${ }^{49}$ Bingen, Dieter: "Einübung in erwachsene Partnerschaft. Die politischen Beziehungen zwischen Deutschland und Polen", in: Bingen, Dieter; Loew, Peter Oliver; Ruchniewicz, Krzysztof; Zybura, Marek (eds.) (2011): Erwachsene Nachbarschaft : die deutsch-polnischen Beziehungen 1991 bis 2011, Wiesbaden, Harrassowitz, p. 35.

${ }^{50}$ Ibidem., pp. 36-37.

${ }^{51}$ Ulatowski, Rafał: "Kryzys czy otwarta dyskusja? Stosunki polsko-niemieckie w XXI wieku", in Franzke, Jochen; Kindelberger, Kilian; Koszel, Bogdan Krämer, Raimund; Sakson, Andrzej (eds.) (2008): The "third Generation". Essays and Articles about polish-german relations, p. 40-49.

${ }^{52}$ Prawda, Marek: "Dialog-Gespräch mit Polens Botschafter in Deutschland, Marek Prawda, über des 20-jährige Jubiläum der Unterzeichnung des deutsch-polnischen Nachbarschaftsvertrags und die weitere Entwicklung der Beziehungen zwischen beiden Ländern", Dialog. Deutsch-Polnisches Magazin, no. 95 (2011), p. 14-15.

${ }^{53}$ Hellmann, Gunther "Reflexive Sicherheitspolitik als antihegmoniales Rezept: Deutschlands Sicherheit und seine gewandelte Strategie", APuZ, vol. 69, no.37, (2013), p. 49-54.

${ }^{54}$ Sikorski, Radosław: Polish foreign minister Radosław Sikorski reminds Berlin of its special responsibility in overcoming the European debt crisis, DGAP, 2011, Available at: https://dgap.org/en/node/20055.

${ }_{55}$ Rede von Polens Staatspräsident Bronistaw Komorowski bei der Gedenkfeier 75 Jahre Beginn Zweiter Weltkrieg" (Polnisch), at

https://www.bundestag.de/dokumente/textarchiv/2014/kw37_gedenkstunde_komorowski/297050 (1.8.2015).
} 


\section{The Economic Aspects of Polish-German Relations}

In the early 1990s German policy toward Poland was dominated by political interests. Economic cooperation played a secondary but positive role. ${ }^{56}$ German industrial associations supported the eastern enlargement of the EU and close economic ties between Germany and Poland. They saw development of economic ties with Poland and other Central European countries as being in Germany's national interest. ${ }^{57}$ Already in the 1990s, they argued that the German investment and trade exchange with this group of countries was of high value. ${ }^{58}$ In the early 1990s Germany used its economic power to support Poland's transformation and integration with the EU.

The main problem for the development of the economic relations in the early 1990s was the issue of the Polish foreign debt. At the end of 1991 it reached USD 41 billion. Poland had been negotiating since the early 1980s with the Paris Club (sovereign creditors) and the London Club (private creditors/banks). In both cases the role of Germany was crucial. The share of state-owned Polish debt owned by Germany was $23.9 \%$ (USD 7.7 billion). The Deutsche Mark was also the second most important currency. The progress in the negotiations with the Paris Club was achieved already in February 1990, but the negotiations with the banks took longer and ended only in 1994. Poland signed a debt restructuring agreement with Germany on March $25^{\text {th }}, 1992$. This may come as a surprise because only the Polish-Italian and Polish-Spanish agreements were signed later. The Polish-German agreement was based on the assumption of a 50 per cent reduction (standard value) of the Polish debt. Banks were not ready to accept conditions such as this. They argued that states followed primary political goals and that they themselves had only an economic goal. Banks also worried that other countries in financial trouble might expect similar favorable treatment as well. In the first part of the negotiations banks were represented by the British Barclay Bank and then since September 1993 by Dresdner Bank. Dresdner Bank belonged to the supporters of favorable treatment of Poland. In consequence, the Heads of Terms was signed on 10 of March 1994 and the final agreement on 14 of September 1994 in Warsaw. ${ }^{59}$

The second important issue of Poland's economic relations with other countries was economic aid. This issue was very intensively discussed in Germany. The value of aid declared by countries of the G-24 for the period of 1990-1994 was USD 21.4 billion. But only USD 4.15 billion was non-returnable. The biggest part of the aid was earmarked for restructuring the Polish debt and export credits. Germany was the key donor. ${ }^{60}$

The third interesting issue is the interest of the authors of the Polish economic reforms in the German model of social market economy. The German economic system was an inspiration for the architects of the Polish reforms. This went so far that social market economy was acknowledged as the economic system of Poland in article 20 of the Polish constitution. ${ }^{61}$

\footnotetext{
${ }_{57}^{56}$ Lippert: Deutschlands spezielles op.cit, p. 133.

57 "Positionspapier des Deutschen Industrie-und Handelstags zur EU-Osterweiterung/Agenda 2000, vorgelegt im Dezember 1997 in Bonn (Auszüge)", in Internationale Politik, vol. 53, no. 6 (1998), p. 71.

${ }^{58}$ Ibidem.

${ }^{59}$ Górniewicz, Grzegorz (2002): Zadlużenie zagraniczne. Polska a kraje rozwijajace się, Bydgoszcz Wydawn. Akademii Bydgoskiej im. Kazimierza Wielkiego.; Sulimierski, Bronisław (1995):"Problemy zadłużenia zagranicznego Polski i próby rozwiązań", Polski Handel Zagraniczny, p. 203-212.

${ }^{60}$ Ners, Krzysztof Janusz: "Pomoc zagraniczna dla transformacji w Europie Środkowej i Wschodniej. Sześć lat doświadczeń", Sprawy Międzynarodowe, vol. XLIX, no. 3-4, (1996), p. 66.

${ }^{61}$ Kleer, Jerzy: "Germany as a Reference Point in the Discussion about the Economic System in Poland", The Polish Foreign Affairs Digest, no. 2 (2002), p. 196-199.
} 
One of the most important dimensions of German-Polish economic cooperation is trade exchange. It has developed very dynamically since the early 1990s. Germany is the biggest trade partner of Poland. In 2013, 25.1\% of Polish exports went to Germany and $21.7 \%$ of Polish imports came from Germany. These numbers prove German dominance in Polish foreign trade. But it is less than in the mid-1990s. The German market was the first goal for Polish exporters. In 1995, 26.6\% of Polish imports came from Germany and 38.3\% of Polish exports went to Germany. The diversification of Polish trade in the last 20 years made it possible to reduce this dependence. ${ }^{62}$

Poland belongs to the group of Germany's ten most important trade partners. In 2014 Poland was the eighth biggest trade partner of Germany. German statistical data show that Poland was the eighth biggest market for German exporters and the sixth most important source of imports. ${ }^{63}$ As shown by the data presented in Table 1, 2014 was the best year for Polish-German trade. ${ }^{64}$

Table 1. Trade between the Republic of Poland and Germany in million EUR

\begin{tabular}{|c|c|c|c|}
\hline Year & Imports & Exports & Balance \\
\hline 2004 & 17397.159 & 17909.105 & 511.946 \\
\hline 2005 & 20024.030 & 20141.953 & 117.923 \\
\hline 2006 & 24201.737 & 23869.733 & -332.004 \\
\hline 2007 & 28947.846 & 26370.121 & -2577.725 \\
\hline 2008 & 31834.2 & 28609.7 & -3224.5 \\
\hline 2009 & 24053.2 & 25685.7 & 1632.5 \\
\hline 2010 & 29362.4 & 31427.0 & 2064.6 \\
\hline 2011 & 34042.1 & 35664.3 & 1622.2 \\
\hline 2012 & 32835.8 & 36057.1 & 3221.3 \\
\hline 2013 & 34005.7 & 38887.5 & 4881.8 \\
\hline 2014 & 36350.2 & 42594.5 & 6244.3 \\
\hline
\end{tabular}

Source: Diverse GUS yearbooks and GUS data cited in: Polsko-niemiecka wspótpraca handlowa w 2009-2014,

http://www.msz.gov.pl/pl/polityka_zagraniczna/europa/stosunki_polsko_niemieckie/wspolpraca_gosp odarcza/wymiana handlowa;jsessionid=191E8B187FDF33A4BDC4455BD73A636F.cmsap2p.

Polish-German trade experienced other important changes as well. First, its overall structure has changed: while the structure of German exports to Poland has remained stable in the last 25 years, the exports being dominated since the early 1990s by products with high added

\footnotetext{
${ }^{62}$ Central Statistical Office, Yearbook of Foreign Trade Statistics of Poland, Warsaw 2014, pp. 47.

${ }^{63}$ Statistisches Bundesamt, Außenhandel Rangfolge der Handelspartner im Außenhandel der Bundesrepublik Deutschland 2014, Wiesbaden 2015.

${ }^{64}$ Wymiana handlowa. Polsko-niemiecka wspótpraca handlowa w 2009-2014, at https://www.msz.gov.pl/pl/polityka_zagraniczna/europa/stosunki_polsko_niemieckie/wspolpraca_gospodarcza/ wymiana handlowa
} 
value, machinery, cars, and chemical products, Polish exports have changed dramatically. In the early 1990s, they were dominated by agricultural products, textiles and commodities. Today their structure is very similar to that of German exports to Poland. Products of the automobile industry are the most important. ${ }^{65}$ Second, it has been based on a new legal framework. Before May 1 $1^{\text {st }}, 2004$ it was trade between an EU Member State and a nonmember. After Poland's accession the full potential of the bilateral trade may be explored thanks to favorable legal conditions.

Table 2. German- Polish bilateral FDI. (In billion EUR at the end of the year)

\begin{tabular}{|l|l|l|}
\hline Year & German FDI in Poland & Polish FDI in Germany \\
\hline 2013 & 26.017 & 1.787 \\
\hline 2012 & 25.410 & 1.774 \\
\hline 2011 & 25.873 & 2.142 \\
\hline 2010 & 23.400 & 1.787 \\
\hline 2009 & 19.732 & 0.273 \\
\hline 2008 & 19.013 & 0.273 \\
\hline 2007 & 19.020 & 0.198 \\
\hline 2006 & 15.442 & 0.200 \\
\hline 2005 & 12.629 & 0.152 \\
\hline 2004 & 9.983 & 0.217 \\
\hline
\end{tabular}

Source: Deutsche Bundesbank (2015), Foreign direct investment stock statistics, Special Statistical Publication 10, Frankfurt am Main.; Deutsche Bundesbank (2011), Foreign direct investment stock statistics, Special Statistical Publication 10, Frankfurt am Main, pp. 14 and 49.; Deutsche Bundesbank (2008), Foreign direct investment stock statistics, Special Statistical Publication 10, Frankfurt am Main, pp. 14 and 49.

The second pillar of the Polish-German economic relations are investments, especially foreign direct investment (FDI). As shown in Table 2, German FDI grows gradually and in 2013 reached the level of over EUR 26 billion, which makes Germany the second biggest foreign investor in Poland, preceded only by the Netherlands. On the other hand, Polish FDI in Germany is a relatively new phenomenon. This comes as no surprise if we keep in mind Poland's poor economic situation in the early 1990s. It is only with economic stabilization in Poland, restructuring of enterprises and their first export success that they were able to invest abroad. ${ }^{66}$ Germany is the top investor in Poland if we take into account the number of foreign

\footnotetext{
${ }^{65}$ Ulatowski, Rafał: Die deutsch-polnischen Wirtschaftsbeziehungen in der europäischen Perspektive, 19902007, Marburg, Tectum, pp. 221-233.

${ }^{66}$ Foreign Direct Investment in Poland in 2014 (EUR), at http://www.nbp.pl/homen.aspx?f=/en/publikacje/ziben/ziben.html
} 
enterprises. At the end of 2013, there were 6,230 German enterprises in Poland. ${ }^{67}$ Germany is (according to NBP data) the fifth biggest recipient of Polish FDI. What is also important is that NBP data shows a much lower value of Polish FDI than the data of the Bundesbank, that is only EUR 933.8 million. $^{68}$

\section{Contemporary Situation of Polish-German Political Relations}

In early 2015 it was possible to indicate four areas where Poland and Germany had different interests. The first one is monetary policy. As an euro area member Germany is interested in rescuing the common currency. Poland, in turn, is interested in keeping the euro area open to other EU Member States. The second one is energy policy. Germany is a front runner in the promotion of renewable energy sources, and German energy policy is closely connected to environmental policy. Poland, on the other hand, is much more concerned about security of supply and the economic dimension of energy supply. This is the reason for its support for an energy system based on domestic coal reserves. The third one was security policy. The Polish preference for NATO and permanent presence of NATO troops in Poland did not enjoy German support. The fourth difference is the countries' perceptions of the conflict in the east of Ukraine. In the beginning of the conflict the idea of sanctions did not enjoy much support in Germany, while for Poland Ukrainian sovereignty plays a crucial role. ${ }^{69}$ Later in 2015 one additional issue was added. The readiness of Germany, declared by the German chancellor, to take in refugees accelerated the wave of immigration, which by far exceeded the expectations of the German government. The migration crisis has dominated the European policy in 2015. The German government tries to impose quotas on the other EU Member States, which are not kindly accepted by Poland and the other Visegrad Group members. ${ }^{70}$

In 2015 Poland saw a change of the president and of the parliamentary majority. This provides a good opportunity to summarize the current state of Polish-German relations. Berlin was the second capital visited by the new president, Andrzej Duda, and the new foreign minister, Witold Waszczykowski, has already visited Germany as well. In this part of the article I will concentrate on these two visits.

President Andrzej Duda visited Germany on 28 August 2015. He met with President Joachim Gauck, Chancellor Angela Merkel, Foreign Minister Frank-Walter Steinmeier and Dietmar Woidke, plenipotentiary of the German government for the relations with Poland. Before the visit, President Duda declared: "I simply like Germany". He also appreciated the German policy toward Russia since the beginning of the Ukraine crisis and the German approach toward its own history. ${ }^{71}$ During the press conference after the joint meeting with President Gauck, the Polish president declared that he was going to build "strategic and best possible relations with Germany". The current security situation in Europe was discussed. He argued in favor of the development of possibilities of learning the Polish language for Poles living in Germany and the German language for Germans living in Poland. Another important part of the discussion was the role of civil societies in the development of the bilateral relations. He indicated that in this area changes and improvements were needed. He prized cooperation in

\footnotetext{
${ }^{67}$ Central Statistical Office, Działalność Gospodarcza Podmiotów z kapitałem Zagranicznym w 2013 r. Economic Activity of Enteties with foreign capital in 2013, Warsaw 2014, p. 52

${ }^{68}$ Polskie inwestycje bezpośrednie za granica - 2014 (EUR), at http://www.nbp.pl/home.aspx?f=/publikacje/pib/pib.html

${ }^{69}$ Cichocki, Marek A.; Osica, Olaf: "Neue deutsch-polnische Agenda. Wie können aus unterschiedlichen Grundlagen gemeinsamer Interessen werden?", Dialog. Deutsch-Polnisches Magazin, no. 111 (2015), p. 51-53.

${ }^{70}$ Kałan, Dariusz (2015): Migration Crisis Unites Visegrad Group, Warszawa, PISM Bulletin.

${ }^{71}$ Schuller, Konrad: "Ein erklärter Deutschland-Freund", FAZ, 27 August 2015.
} 
areas such as youth exchange. The conclusion of the visit was that the last 25 years were a great success in Polish-German relations and that the two countries should develop a strategy for the next 25 years. ${ }^{72}$ President Gauck also appreciated the current state of Polish-German relations. He emphasized the two great successes of both countries: Poland's accession to NATO and to the EU. He talked about "a great reservoir of mutual respect and trust" between two countries. ${ }^{73}$ But he also pointed out some differences between the two countries. These were: immigration policy (the refugee issue), the policy towards Ukraine and the future role of NATO. These topics were also discussed between President Duda and Chancellor Merkel. $^{74}$

The second visit was paid by Witold Waszczykowski, Poland's new foreign minister, on 28 November 2015. He met with his German counterpart - Frank-Walter Steinmeier. They discussed the key and most controversial issues of the current situation in the EU: the migration crisis and the situation in Ukraine. The issue of immigrants and refugees is what particularly divides the two governments. Minister Waszczykowski declared in Berlin that the key goal of the EU should be to ensure security of the EU's borders. He pointed out that the relocation mechanism, agreed upon by the EU in September 2015 would not solve the problem. $^{75}$ The mechanism prescribes quotas for Member States. Romania, the Czech Republic, Slovakia, and Hungary voted against it. Finland abstained from the vote, and Poland accepted the plan, although the government had previously opposed it. ${ }^{76}$ Migration was also the main topic of the interview given by Minister Waszczykowski to the German press. He indicated that NATO still had no troops in the new Member States and blamed this situation on Germany. He argued that Germany was taking Russian interests more seriously than the security interest of Central European countries. ${ }^{77}$ This allegation concerns energy policy as well. As indicated earlier, in the early $21^{\text {st }}$ century Poland and Germany argued about the construction of the Nord Stream gas pipeline. In June 2015, Gazprom, Wintershall, E.on, Shell, OMV, and Engie agreed on the construction of Nord Stream II. Although Chancellor Merkel sees this project as a commercial activity, the countries of Central and Southern Europe interpret it as a threat to their energy security and economic interests or as an asymmetric approach to the EU policies regarding Russia. ${ }^{78}$

\section{Conclusions}

Polish-German relations developed favorably in the last 25 years. The two countries had the same strategic goals in the early 1990s. EU and NATO enlargement were at the top of the priority list of both countries. Of course, this does not mean that there were no diverging

\footnotetext{
${ }^{72}$ Prezydent Andrzej Duda z pierwsza wizyta w Berlinie, 28 August 2015, at http://www.prezydent.pl/aktualnosci/wizyty-zagraniczne/art,3,w-piatek-prezydent-duda-z-pierwsza-wizyta-wberlinie.html.

${ }^{73}$ Federal President Joachim Gauck at a lunche on the occasion of the first official visit of Polish President Andrzej Duda at Schloss Bellevue, 28 August 2015, at http://www.bundespraesident.de/SharedDocs/Downloads/DE/Reden/2015/08/150828-Antritt-Polen-Dudaenglisch.pdf? blob=publicationFile.

${ }^{74}$ von Marschall, Christoph: Polens Präsident trifft Merkel und Gauck Andrzej Duda - der schwierige Gast, 28 August 2015, at http://www.tagesspiegel.de/politik/polens-praesidenttrifft-merkel-und-gauck-andrzej-duda-der-schwierige-gast/12250422.html.

${ }^{75}$ W Berlinie o wspótpracy polsko-niemieckiej, 27 November 2015, at http://berlin.msz.gov.pl/pl/aktualnosci/w berlinie_o_wspolpracy polsko_niemieckiej.

${ }^{76}$ Migrant crisis: EU ministers approve disputed quota plan, 22 September 2015, at http://www.bbc.com/news/world-europe-34329825.

${ }^{77}$ Wo bleibt die Solidarität Deutschlands?, 14 December 2015, at http://www.fr-online.de/politik/polen-wo-bleibt-die-solidaritaet-deutschlands-, 1472596,32924668.html.

${ }_{78}$ Pipeline-Projekt Nordstream 2: Heftiger Streit zwischen Merkel und Renzi auf EU-Gipfel, 18 December 2015, http://www.spiegel.de/wirtschaft/soziales/merkel-und-renzi-streit-ueber-nordstream-ausbau-a-1068611.html.
} 
interests, but governments of the two countries focused on the priorities and played the divergences down. They came to the spotlight more strongly only once the EU enlargement negotiations were closed. In the early $21^{\text {st }}$ century Poland and Germany went into a phase of intensive discussion. The differences were big and included the most important elements of bilateral relations but also European and transatlantic relations. Then the Polish government decided to reduce tensions. The speech delivered by Minister Sikorski showed the priority that Polish government gave to the relations with Germany. But in current Polish-German relations divergences are once again present. The key topic is migration policy. German behavior is criticized not only in Poland but also in many other EU Member States.

In the current Polish-German relations, the most important issues discussed do not have a strictly bilateral character. Common interests and differences concern issues of European or international policy. In this sense they are very similar to French-German relations, which confirms the success of the design of the Polish-German relations since the early 1990s.

In the last 25 years Germany has successfully used economic means to achieve political and economic goals in its relations with Poland. On the one hand, it was the power of attractiveness. The German model of social market economy is highly appreciated in Poland. German economic power was also sufficient to convince the other Member States to agree to the eastern enlargement. Germany developed intensive economic relations with Poland. Today they constitute a solid background for the economic and political cooperation between the two countries.

For the last 25 years, Polish-German relations have experienced a great deal of change. During the accession negotiations Poland was highly dependent on Germany. The accession changed this structural weakness of Polish foreign policy, creating new opportunities for the designers of the Polish foreign policy. 